\title{
QUALITY AND QUANTITY AS INDISSOCIABLE DIMENSIONS OF RESEARCH
}

\section{QUALIDADE E QUANTIDADE COMO CATEGORIAS INDISSOCIÁVEIS DE PESQUISA}

Leilah Santiago Bufrem a

\begin{abstract}
Objective: To theoretically demonstrate the relations between the quality and quantity dimensions and their indissociability in research, arguing that the ways of producing knowledge within a scientific field is conditioned to the researchers' vigilance over the system of objective relations and, thus, is a practice governed by a particular metascience. Method: The argument is built from a philosophical theoretical framework. Results: While it is necessary to identify predicates such as quality and quantity to distinguish and analyze the scientific object, these are constituent aspects of the totality of the perceived object, and it is impossible to study them separately. Conclusion: It is necessary to look carefully at the way scientific research is constructed and communicated, including its explanations and statements based on the predicates' relational aspects in their double determination, investigation, and exposition, which relates to the process of appropriation and critical-rational explicitness.
\end{abstract}

Descriptors: Scientific method. Research predicates. Complementarity. Meta-science.

\section{INTRODUCTION}

The ways of producing knowledge within a scientific field are determined by the conditions under which the object of study is configured, by the full complexity of its social reality, and by the research agents, as parts of the conjuncture of objective relations that shape the research. Governed by specific meta-sciences, the forms of intellectual work acquire meaning upon the adoption of a particular methodologies, given the need to conceive a set of procedures that are adequate to the proposed scientific investigation. The researcher, intentionally focusing on the object of study in its entirety and seeking to

\footnotetext{
a Doutora em Ciências da Comunicação pela Universidade de São Paulo (USP). Pós-doutora pela Universidad Autónoma de Madrid. Email: santiagobufrem@gmail.com
} 
understand its correlations within possible limits, is concerned about how to construct explanations and statements and how to verify them, as they reflect on their own investigative action, in an effort to validate and attest to their veracity. When trying to objectify and expose the research findings, the researcher employs a specific language to represent the procedures while guided by the expectation of formally structuring the scientific object. They do so by adopting a style to express the findings, making the interpretive models explicit, and naming and describing the procedures according to conventional ethical and academic standards.

The motivation of this study concerns the inappropriateness of attributing the qualitative or quantitative predicate to any scientific research. Based on the assumption that the method or combination of specific procedures and techniques to be employed in the investigation is defined during the construction of the research object or problem, we intend to argue in favor of constructing the research object while preserving its integrity and conception as an organic whole. In social sciences research, one of the obstacles to this awareness has been the use of the adjectives "qualitative" or "quantitative" to denote different natures of study. We highlight this designation because we consider it an inadequate and partial way of expressing the understanding of the object of investigation.

With this in mind, the reflection hereby outlined is grounded in philosophy, on the assumption that the scientific and philosophical dimensions complement each other in the construction of knowledge. We see the return to Aristotelian metaphysics and the dialectics of historical materialism as a promising way to advance the discussion on the relationship between quantity and quality in research, both in the social sciences in general and, specifically, in information science.

To this end, after this introductory section, we will address the definition of the terms being discussed here; the ontological and logical implications of the concepts of quality and quantity in relation to the nature of the research and its denomination; the theories that support the argument, with their assumptions and generalizable propositions, and provide a framework for the analysis, as well as their points of convergence. In the final considerations, we will emphasize the 
importance of looking at quality and quantity as indissociable elements, both for the comprehension of the object in the research and for its description.

\section{TOWARDS AN UNDERSTANDING OF THE TERMS}

Some of the requirements of scientific knowledge, such as precision, order, and systematization, are historically related to Aristotle's construction of categories, with emphasis, for this study, on the concepts of quality and quantity. The fact that, although closely related, these terms represent distinct concepts led to the use of a stipulative definition - based on previously known concepts as a guide for the specific discussion to be carried out, for as long as it serves the purpose of the work. This first step in seeking an adequate definition for the ordinary use of the terms implies the initial rejection of the dichotomous opposition between quality and quantity when it comes to understanding any object of research, just as one might do with other pairs of terms, such as those presented by Saussure (2001) in his Curso de Linguística Geral. Although he does not use the term dichotomy, four pairs of concepts illustrate his analysis: diachrony versus synchronicity; language versus speech; signifier versus signified; and paradigm versus syntagma.

For the purpose of this study, the terms quantity and quality are construed as predicates, attributes, or modes of manifestation conferred on a substance or object of study, which make up its being and its mode of being. Given that the reality we are analyzing is understood in its qualitative and quantitative elements, its relationships with other beings or things, its condition or situation relative to the period or the place occupied, and by performing actions or suffering them from other beings, this study dismisses the notion of quality and quantity as dichotomous, like the other pairs previously mentioned, following Latour's critique (LATOUR, 1994). Latour (1994) attributes this dichotomous construction to a demand for the "purification" of entities or objects and relates it to the epistemological project of Western modernity when the individual-society dichotomy emerged alongside other dualisms such as subject-object, theorypractice, nature-culture, and nature-artifice. As ways of expressing disjunctions or oppositions between dimensions of the real, these dualisms generate false 
problems. They are the result of a logic that sees beings - whether physical, biological, psychic, or social - as a priori given, without considering the specific processes that engender them, as Paul Veyne (1982) argues.

If we accept that to achieve knowledge it is necessary to consider these specific processes and pursue a path of observation and discovery, starting with the evaluation of existing methods and their adequacy to the objects, purposes, or objectives of the research, the scientific method is then understood as the set of procedures that are applicable to the in-depth investigation of a given reality as the object of study, whose characteristics must be acknowledged. This set of procedures is not always explicit, because it is tacitly part of the scientist's activity. However, careful explicitness should prevail when communicating a research to the scientific community.

A being-oriented conception is measured by its ontic relevance, which is understood as a distinct way to conceive the course of knowledge of the research object, especially in terms of its relevance to the practical dimension of investigation, in favor of its organic construction and based on the contradictions of reality. Resorting to Heraclitus' metaphor of the bow and the lyre, in his fragment 51 (HERÁCLITO, 1973), has served to illustrate how contradictions are inherent to existence. As he concludes his reflection on the harmony of contrary tensions, Heraclitus describes coherence as that of the bow and the lyre, simultaneously tense and stable (HERÁCLITO, 1973). In the making of the lyre, for example, it is necessary to bend the wood into an arch and tie the strings to it, revealing that while the strings 'struggle' to bend the bow, the bow in turn 'struggles' to snap the strings. Nietzsche (2007) refers to this tensed movement in Ecce homo, pointing to the "tragic wisdom". Quoting Heraclitus, who best knew how to describe this perspective among the Greeks and in whose vicinity, he claims to feel "altogether warmer, better disposed than anywhere else", Nietzsche (2007, p. 47) refers to tension as a guarantee of balance.

The affirmation of transience and destruction, the decisive feature of any Dionysian philosophy, saying 'yes' to opposition and war, becoming, with a radical rejection of even the concept of 'being' - in this I must in any event acknowledge ideas that are more closely related to mine than any that have hitherto been thought (NIETZSCHE, 2007, p. 47-48). 
The imposition of one of the opposites, with its hegemonic force, would extinguish this harmonic movement and prevent things from existing - this is why tension is the guarantee of balance. Nietzsche's thought reaches this final understanding in his autobiography, coming all the way from the conception expressed in his first work, in which he conceives the emergence of tragic art among the Greeks as the result of the harmonic conjunction of two opposing artistic impulses, which he called Dionysian and Apollonian (NIETZSCHE, 2007). This is very much a reflection of the influence of Heraclitus' conception of harmony in tragic thought, because the stability generated by the assumption of one of the opposites and its hegemonic force would destroy harmony, halting the existence of things. Tension would therefore be the guarantee of balance, and dissension, the condition for harmony.

The result of this interaction is balanced, in the same way that knowledge is harmoniously realized from a relational point of view, considering facts and their determinants, as well as facts in relation to each other. Therefore, we have accepted the notion of academic fields with their rules for valuing agents and structures, whose criteria include the possession of capital and various power resources. There is a prevalence of a relational perspective that integrates agents, structures, habitus, and types of capital according to rules pertinent to each field of the social world, a conception that may be summarized in the statement: "the real is relational" (BOURDIEU; CHAMBOREDON; PASSERON, 2004, p. 109, our translation).

We may recognize this process by questioning how these elements "participate" in this relationship, how they are integrated in the two dimensions of succession, both in transformation, from a diachronic point of view, and in simultaneity, from a synchronic point of view. In the same way, we may question how each one has a meaning and a role derived from its interaction with the others, in the specific moment in which the elements coexist in a given time. This relational point of view allows us to consider the whole in its regularity and homogeneity. 


\section{THE INNOCUOUSNESS OF THE QUANTITY VERSUS QUALITY ARGUMENT}

Resulting from different epistemological positions, the methods used to conduct research have been transformed just like science itself, translating ways of thinking, observing, analyzing, and interpreting reality. Starting with the ancient Greeks, going through the scholastics, the moderns, and the contemporaries, there has been a succession of contributions to the evolution of this process of scientific construction and the interpretations that arise from it. According to Althusser's conception about the science of historical social formations, it was Thales of Miletus who introduced the continent of mathematics to knowledge, while Galileo introduced to scientific knowledge the continent of physical nature and Marx, the continent of history (ALTHUSSER, 1979). These developments have contributed to epistemological formations, methodological configurations, and a wide diversity of research in terms of the nature of the research, the sources used, the procedures employed, and the qualitative or quantitative dimensions that characterize it. The reflection launched in this research does not concern whether there is a dialogical exchange between researchers about what is improperly called qualitative research and quantitative research. Neither does it intend to adopt an "ecumenical" position, because it is not a matter of reconciling opposites or divergent ways of doing science, but of understanding the scientific process in its integrity, as an intentional action.

If by method, according to its etymological meaning that dates to Plato, we mean the direction taken by the investigation, then this direction can stem from different options or perspectives, such as the choice regarding the quantitative and qualitative aspects of the study. In this regard, André (2002) alerts to the use of the term 'quantitative research' to identify positivist research science, which she argues is a reductionist approach. "To associate quantification with positivism is to lose sight of the fact that quantity and quality are closely related" (ANDRÉ, 2002 , p. 24, our translation). She also criticizes the use of the term "qualitative" in a broad and generic way, advocating instead the use of more narrowly defined terms to differentiate research techniques or to designate the type of data 
obtained, i.e., "the use of more precise designations to determine the type of research conducted" (ANDRÉ, 2002, p. 24, our translation).

The controversial dichotomy between these two aspects has widely affected current discussions about scientific work. Arguments against the quantitative emphasis are especially supported by critics of positivism, such as Jensen and Jankowski (1993), whose main argument is based on the consensus that it is impossible to adequately examine and value fundamental issues in the social sciences through predominantly quantitative procedures. This is because the nature of human facts requires distinctive data treatment and analysis practices, with appreciation of their specific characteristics, relationships, and qualities.

Weingand (1993), in turn, presents two favorable arguments used by the advocates of the methods some refer to as quantitative: the possibility, in empirical research, to isolate the experimental variable and its temporal impact, or to repeat an experiment several times, using different groups of subjects. This discussion, however, should go beyond the investigative conduct that began in the 17th century, resulting from the success of experience as a source of knowledge, when methods, known as quantitative, gained prominence in the humanities and social fields. In effect, the industrial revolutions led to transformations in the scientific work, as well as new configurations of scale and nature that gradually reduced the space of the academic and free science in favor of another, more conditioned to the State and the industry. Thus, the little science of the past would have been replaced by the big science, with emphasis on the quantifiable aspects of the research object, both in the natural and physical sciences and in the human and social fields. Solla Price's pioneering work on this emphasis on scientific production and publications became known on the Sixth International Congress for the History of Science, held in Amsterdam in 1950 (SIXTH INTERNATIONAL CONGRESS FOR THE HISTORY OF SCIENCE, 1951), with repercussions in two works: Science Since Babylon (PRICE, 1961) and Little Science, Big Science (PRICE, 1963), which disseminated his alternative and not always concordant conceptions. 
Currently, different perspectives alternate with the positivist paradigm. However, some antagonisms remain between the quantitative and qualitative approaches, as well as ways of re-articulating the elements of research by which data of qualitative and quantitative nature are integrated. In the attempt to overcome these antagonistic movements, it is possible, methodologically speaking, to resort to Habermas' reflections on the two functions of measurement (HABERMAS, 1994): data can guarantee the simplification of controversy on existential questions and, given its possibility of repetition, the intersubjectivity of experience. As to illustrate this argument, metric studies have been chosen for empirical evaluations and applications, being influenced by situational issues from a reality that, under the perspective defended here, is not annulled by the modes of observation and studies directed to them but rather highlighted. This shift in perception provides options to overcome the contradictions between the qualitative and quantitative aspects of a study. Moreover, the possibility of integrating them in the construction of knowledge is achieved through the use of multiple strategies, given the interdependence between scientific development, changes in context, and creativity in research.

Thus, what are called "qualitative approaches" have been more recurrent in disciplines such as sociology, philosophy, and sociocultural anthropology, fields in which the objects of study require a certain type of analytical treatment that emphasizes relationships and the value acquired by the characteristics and behaviors observed. However, due to the approach used in their studies, these fields have received criticism that question the value of their research. Among their critics are the opponents of sciences that emphasize the qualitative expression of their object.

This study argues that the improperly named "qualitative research" and "quantitative research" do not necessarily represent alternatives to the quantitative or qualitative studies if we consider the necessary qualitativequantitative complementarity when analyzing human or social phenomena. In this case, this complementarity stems from the very nature of any investigation since it privileges the dynamic relationship between the real world and the subject. In 
other words, the subject-observer integrates the knowledge process by attributing meaning to the phenomena and the perceptible relations between them.

In this context, we highlight the possibility of integrating the two modes of reality perception in the production of knowledge, not only by arguing that "qualitative research" can be used alongside "quantitative methods" but also considering the contribution of the qualitative process to describe the experimental design. The argument we present here goes beyond the conception of a methodological "possibility" that comes from complementary methods and triangulated research, followed by an interdisciplinary re-articulation of research that values practices more suitable for methodological choices in the humanities, social sciences, and applied social sciences. What we defend, based on arguments founded on the Aristotelian doctrine and the laws of dialectics, is the impossibility of carrying forward any attempt to separate inseparable aspects of the object in the scientific investigation process.

\section{QUANTITY AND QUALITY AS PREDICATES}

In the history of Western philosophy, thinkers have attempted to understand the possibilities and conditions of knowledge, the ways of producing it, and its relations to what is considered truth. The scope of these discussions allows us to identify the relationship between the concepts of quality and quantity, which are singularly present in Aristotle. Aristotle's Organon, a collection of five treatises whose purpose is to instrumentalize knowledge, presents integrated and organically composed content in the following texts: Categories; On Interpretation; Prior Analytics; Posterior Analytics; and Topics. Its instrumental characteristic has been recognized in several fields of knowledge, including, with particular relevance for this study, Information Science (ARISTÓTELES, 2005). Authors in this field, such as Dahlberg (1992, p. 65-71), have revealed the presence of the philosopher and its importance in the field's domains by listing the researchers' seven philosophical bases as intellectual tools for their classificatory endeavors: (a) Logic, which is based on Aristotelian logic studies and from which derives the "Referent-oriented, Analytical Concept Theory"; (b) Theory of Science, from which derives the concepts of "knowledge element" and 
"knowledge unit"; (c) Epistemology, which allows us to identify and differentiate the relationships between concepts through the understanding of cognition, "mental act and the ability of the mind to compare something new with what has already been acquired in different previous acts"; d) Ontology, as the Science of Being, of all that exists, which is represented by the ten Aristotelian categories; e) Phenomenology, which allows us to clarify concepts and from which derives the "hermeneutic interpretation"; f) Alethiology, which provides scientific structure and criteria that favors the identification and representation of truth; g) Metaphysics, or science based on the experience of reality, whose main focus is to analyze the foundations, conditions, laws, meanings and purposes of beings in general. When analyzing these knowledge domains in their relations with aspects of Knowledge Organization (KO) contents, Dahlberg (1992) considers language the only support for concepts, words, and terms.

This relationship between philosophy and $\mathrm{KO}$ is also highlighted by Aranalde (2009), who presents the theory of categories according to the elaborations of Aristotle, Kant, and Ranganathan in the search for subsidies to identify them as fundamental and indispensable principles of $\mathrm{KO}$, considering the objectives of each categorical system. The author concludes that Aristotle conceives his fundamental principles to express the modes of being, whereas Kant relates them as modes of thinking, and Ranganathan identifies the categories as modes of classifying.

It is precisely this instrumental meaning of knowledge, its ways of expression and representation, that grants Logic both the condition of assumption and requirement for the other philosophical disciplines and its close relationship with Metaphysics. On the one hand, Metaphysics studies the "being as being" and its properties, which means it investigates not only the substance but what is inherent to it, as well as the contraries - antecedent and consequent, genus and species, the whole and the part - and other notions. On the other, Logic instrumentalizes this study. The discourse on categories has its origin in Aristotle, even though the problem concerning the modes of manifestation of the being goes back to Plato (PLATÃO, 2011), especially in the Sophist's doctrine on the five Great Kinds: being itself, change, rest, sameness, and difference. Although 
not a part of the Organon's ordered plan, that is, the expository treatise of Aristotelian logic (ARISTÓTELES, 2005), the categories have been recognized as a kind of introduction to it. Other Aristotelian texts, all written during his experience as teacher and preceptor at Plato's Academy and, later, as head of the Lyceum, deal with the philosophy of nature (treatises on physics, biology, cosmology, and psychology), metaphysics (what is called first philosophy), ethics and politics, and rhetoric and poetics. The Categories consist of three parts: PrePredicamenta (ch. 1-4), Predicamenta (ch. 5-9), and Post-Predicamenta (ch. 1015). In the Pre-Predicamenta, Aristotle discusses some semantic relations, then presents the division of beings into four kinds and the canonical list of the ten categories. In the Predicamenta, he discusses at greater length the categories of substance, quantity, relatives, and quality, also providing a cursory treatment of the other categories (11b1-14). Finally, in the Post-Predicamenta, he discusses concepts concerning modes of opposition, priority and simultaneity, and motion. To attribute something to a subject, one needs the predicates or categories that designate the being in many ways. When Aristotle names the eight categories in his treatise predicates, he refers to both the structure and the mode of being of the substance or essence (ARISTÓTELES, 2000). The discussion about essence, in turn, leads him to reflect on the metaphysical conception that defines the concept of essence as what a thing truly is. This conception raises discussions about the meaning of "being something" or being the "truth" of something, suggesting the idea of truth as what lies beneath appearances. To answer this question, the philosopher reveals the need to consider the being as both existence and essence. Furthermore, in an attempt to overcome this ambiguity, he defines the essence of a thing, in one sense, as substance and the determinate being, while in the other, as each of its predicaments, such as quantity, quality, and other modes of the same nature (ARISTÓTELES, 2000). Thus, as constitutive elements of being and modes of being, categories are attributed to a substance or essence. "Each one of the things said without any combination mean either substance, or quantity, or quality, or relation, or where, or when, or being-in-a-position, or having, or doing, or suffering" (ARISTÓTELES, 1b25, 2000, p. 73, our translation). 
Isolated, therefore, "categories cannot be affirmed or denied, they are neither true nor false, they simply exist, according to the Aristotelian system, and serve for the understanding of propositions" (SALES; GUIMARÃES, 2017, p. 129, our translation). With this assertion, Sales and Guimarães (2017, p. 129, our translation) advocate for the identification of categories in favor of "a deeper analysis and understanding of the knowledge we have about the world and things in the world".

Hence, it follows that every reality is known for presenting not only qualities, such as the condition of being mortal, immortal, finite, infinite, good, bad, among other possibilities, but also quantities, such as one, many, some, little, much, big, or small. Therefore, substance relates to "others" as equal, different, similar, greater, lesser, higher, lower, and is also located somewhere like here, there, near, far, above, below, in front, behind. Consequently, it is also situated in time, that is, before, after, now, yesterday, today, tomorrow, day, night, always, never. It performs actions or does something, like walking, reading, thinking, sleeping, climbing, falling, catching, growing, being born, dying, germinating, fruiting, blooming, but also suffers actions from other beings, like being cut, being caught, being killed, being helped, being pulled, being attracted, being taken away, being cured, being poisoned, being stolen, among so many other possibilities.

Categories or predicates, on the other hand, can be essential or accidental, i.e., they can be something necessary and indispensable to the very nature of a being, or they can be something that a being possesses by chance or that happens to it by chance without affecting its nature. It is important to emphasize, however, Aristotle's (2000) lesson on the "combination" of things among themselves: "Each of these things already said, in and by themselves, affirms nothing, but it is through their combination with each other that the affirmation happens. Indeed, every statement seems to be true or false, whereas for things said without any combination, none is true or false."

Aristotle's lessons also facilitated the work of other philosophers in their interpretations about the manifestations of being, as did Kant (1988) in his Crítica da razão pura, where he reflected on experience as a producer of sensations. 
For the philosopher, experience produces sensations that, when gathered around an object in space and time, form the particular impression of the object, that is, perception. Thus, reason would order the perceptions around the categories of quantity, quality, relation, and modality, constituting the structure through which they are classified. He conceives the a priori forms of knowledge, space and time, as crucial to perception. Categories would therefore be the structure by which perceptions are classified and shaped into ordered concepts of thought.

Aristotle contributed with both his metaphysics and his logic to the understanding of what has been considered the essence of a thing, meaning substance, the fundamental category of his treatise, and the determinate being. $\mathrm{He}$ considers as predicaments quantity, quality, and the other categories related to substance, which is a more resistant and more permanent category than the other ones. In this way, the philosopher favored the possibility of knowledge and what would become scientific knowledge, offering a way to meet the challenge of making a science of corruptible beings, instrumentalized by the categories. Perhaps the most significant relationship, not only for scientific work but also for $\mathrm{KO}$, is the one established between the concepts of extension and comprehension (or intention) and their categorical correlates: quality and quantity. The reason for this is that a concept can be understood from two points of view: that of extension, i.e., the set of objects to which a given concept applies or to which it can be applied as an attribute, and that of intention or understanding, which is the set of characteristics or qualities stated for the definition of the concept, that is, its signification. The special attention given to this relationship contributes to the construction and definition of the research problem in its contextualization, as well as to the definition of hypotheses, objectives, and methodological procedures. Thus, it allows us to understand the reality or research object in its qualitative and quantitative predicates, which relate to each other and other beings or things in their condition or situation concerning the time and place occupied and performing actions or suffering them from other beings. 


\section{A DIALECTICAL CONCEPTION OF KNOWLEDGE}

Since the argument of this study is the impossibility of dissociating the qualitative and quantitative aspects of a research object's reality due to ontological and gnoseological argumentations, we resort, as previously stated, to a critical conception of philosophical dualisms.

Once the assumption that scientific development is interdependent on changes in a broader research scenario is accepted, the nature of studies that have been inappropriately called qualitative or quantitative can be defined from the scientific work in coexistence with a reality under study.

Just as quality cannot be dissociated from quantity, the relationship between theory and practice, as praxis, has a dialectical nature. Theory cannot be conceived without practice, which gives it content for reasoning, and vice versa. Dialectical materialism as an analytical logic is based on the laws that mobilize the dynamics of phenomena, and especially on the existence of a unity composed of contraries and self-dependents. These elements combine and mobilize each other in constant dynamics of transformation - be it in quantities or qualities, be it in the social or natural universe.

When defending the materialist nature of dialectics, Engels (2000) devises general laws, common to both human history and nature, narrowing them down to three: the law of the interpenetration of opposites; the law of the transformation of quantity into quality; and the law of the negation of the negation. Although the three are interconnected, the law of the transformation of quantity into quality is the main focus of this article, since it contributes to the argument that when things change, they do not always change at the same pace. The process of things changing is conducted through "leaps" that result from the minimal changes in quantity added up until they trigger, at a certain point, a qualitative change, when the being becomes the other. Through this law, it is possible to investigate the nature and models of the development process, revealing how the new surfaces and how the old is replaced by the new. In other words, "the process of transformation through which they exist has slow periods (in which small quantitative changes take place) and periods of acceleration". Thus, it can be 
said that all things have characteristics that are quantitatively determined and properties that come from the set of these characteristics, establishing quality as an essential property of the material system. The same happens with material systems and their quantitative determinations, such as size, volume, weight, intensity, and structural arrangement. Hence, quality and quantity always constitute an indissociable unity.

Therefore, we argue that scientific work should be the object of reflection on these dynamics, and self-reflection on its production and communication structures. An authentic science of science, as Bourdieu (1976) argues, can only be considered as such if it radically refuses the abstract opposition between an immanent or internal analysis - better defined as epistemology - and an external analysis, connecting these problems with the conditions of their emergence.

In this social environment, the expression of reality manifests itself and is made of indissociable elements, quantitative and qualitative, objective and subjective, particular and universal, all intrinsically related. Its separation can only be accomplished as an abstraction for didactic purposes. However, if we analyze these dynamics, or the "everyday life," according to Lefebvre's (1991) argument, it would be necessary to acknowledge all these aspects as interconnected so that the scientific explanation comprehends the object as a dialectical unity, becoming consistent with the method itself.

Therefore, it is understood that if, on the one hand, separation, as part of the analytical process, unlike fragmentation, allows a partial in-depth study of the object, with the identification of its elements, it requires returning to the articulated group on the other, to ensure an end to the cycle of knowledge process. In this case, a double move is performed, inductive and deductive, from the whole to the part and from the part to the whole. As Kosik (1976) argues:

A dialectical conception of totality means that the parts not only internally interact and interconnect both among themselves and with the whole, but also that the whole cannot be petrified in an abstraction superior to the facts, because precisely in the interaction of its parts does the whole form itself as a whole (KOSIK, 1976, p. 23).

We assume that the representations of scientific trends and the considerations based on which different researchers reform or reinforce their 
ways of producing science influence each other. Thus, we define this mutual influence as a factor in the transformation of the ways science is produced. Likewise, these ways of producing science are historically transformed and improved, both from the individual point of view of the researcher as they become aware of what they are doing and from the transformations carried out in the field of knowledge itself, mobilizing the relationships in the dynamics of the research process. This process implies a knowledge based on proper theory, on the analysis of concrete and conjunctural forms and spaces, on political and technical aspects, and on a permanent questioning and criticism of current concepts and practices. All research is guided by theoretical frameworks and methodological procedures, not as approaches, but as dimensions that are part of a dynamic process. The dimensions provide the researcher, in the task of developing their object of research, a diversity of changes and phenomena that affect them continuously and constantly. These changes influence the development of the research object and reinforce the possibility of thinking organically about the problem posed by the researcher, its purpose, justification and motivations, hypotheses, objectives and goals, materials, strategies, instruments, predictions, and subjects involved in the process.

When talking about his journey as a teacher, Luria (1992) refers to an early stage, when subjects had already received preliminary instructions and were engaged in collective discussions regarding important social issues, then made the transition to abstract thinking. Once ideas and experiences are born, they transform how people use the language, turning words into the main agent of abstraction and generalization. Thus, "they increasingly use categorization to express ideas about reality" (LURIA, 1992, p. 78, our translation).

In the present case, quality and quantity are both aspects of the object as a whole; aspects that require an in-depth analysis to be recognized as a metascience matter - that is, related to science when it comes to its own constitution and process in the search for knowledge, how it develops its explanations, and how it verifies their validity and veracity. Therefore, it is not important to discuss the advantages, disadvantages, positive or negative aspects of adopting 
qualitative or quantitative research approaches, because this distinction does not make sense considering the assumptions and conceptions adopted.

There is a misunderstanding in the separation between the qualitative and quantitative aspects of a phenomenon or object of study because when we conceive reality as a totality, the mistaken or dichotomous understanding of quality and quantity is gone. Totality refers to every aspect of reality, without exceptions, including quality and quantity, indissociable categories. Thus, no data can be analyzed if we take into consideration only one of these aspects, be it quantitative or qualitative, because the attribution of quality is not reduced to the rejection of quantity, and vice-versa.

Marx's dialectical method, in its double determination - research and exposition -, refers to the process of appropriation and critical-rational explanation of the immanence of the object by the subject, two indissociable instances, since the object can only be exposed after being investigated and critically analyzed in its essential determinations. Opposing uncritical positivism - common to modern classical economics that takes the object as a factual immediacy, without the mediation of thought - , the materialist dialectic also opposes uncritical idealism, typically speculative, as well as Hegelian dialectic, whose object results from an abstract construction of thought, which summarizes everything and operates from itself. When explaining concrete totality, Kosik (1986) refers to the social phenomenon as a historical fact if it is studied as part of a particular whole in its double action of defining itself and defining the whole, that is, producing and being the product at the same time, acquiring its own authentic meaning and giving meaning to something else. This mutual connection and mediation of part and whole means, at the same time, that isolated facts are abstractions, artificially detached from the whole, truth and concreteness.

When research starts conceiving reality as a totality, it refers to every aspect and determination of said reality, with no exceptions, including quality and quantity, because no data, object, or knowledge can be analyzed partially or by privileging one aspect over the other. The scientific view, in any method of observation, is a view of the object of study in action, in the time-space in which it acts. An observing view wants to capture it in its totality, from a historical 
perspective of qualitative and quantitative changes, as well as contradictions. This was the view introduced to philosophical tradition back in ancient Greece by Heraclitus.

To say that the "qualitative approach" is a research practice without a solidly structured proposal, allowing the imagination and creativity of researchers to propose studies with new approaches and innovations, can lead to misinterpretations or the perception of what is called qualitative as a lack of organic structuring. On the other hand, imagination and creativity can be found in research of any sort, from those conducted in laboratories, with rigorous observation and measuring instruments, to those that embrace the interpretation of objects that are difficult to identify when isolated from the researcher.

\section{FINAL CONSIDERATIONS}

This study was motivated by the argument in favor of a scientific investigation focused on the object in its totality, avoiding the dichotomization of quality and quantity not only in the process of producing science but also in its process of communication. The aim was to argue theoretically about the relationships between these two categories and their indissociability in research practice.

The question posed refers to the impropriety of assigning a qualitative or quantitative characteristic to a research's conception and description. The existence or lack thereof of a dialogue between researchers on the topic, or the preferences between what is improperly called qualitative research or quantitative research, was not in question, as it is not a matter of reconciling interpretations or preferences, highlighting advantages, disadvantages, virtues or vices of such practices. We have tried to demonstrate the misunderstanding that comes from the separation of quality and quantity in a research process, as if it were something logically or ontologically possible.

Therefore, according to the arguments hereby discussed, conducting research is only possible if reality is conceived in its totality, avoiding a mistaken or dichotomous understanding of quality and quantity. Totality, or the synthesis of the multiple determinations coexisting within the being, in a contradictory way, 
is accepted as a fundamental category of dialectical thought. Among these multiple determinations, the whole is composed of qualities that are not present in isolated parts, nor juxtaposed parts. The sensory concrete is part of the sensory-mediated representation of the material world in our mind.

The concrete is concrete, because it is a combination of many objects with different destinations, i.e. a unity of diverse elements. In our thought, it therefore appears as a process of synthesis, as a result, and not as a starting point, although it is the real starting point and, therefore, also the starting point of observation and conception (MARX, 1904, p. 293).

This conception is not seen as the result of a subject-object relationship in an individual and contemplative way, nor as a continuous linear relationship beginning with sensation to reach knowledge, according to Marx's conception (MARX, 2008). It comes from a process of constant repetition that is part of the exchange between human beings and nature through work, in producing their subsistence. Thus, totality refers to every aspect of reality, without exceptions, including quality and quantity, indissociable properties, which is why no data can be analyzed under only one of its aspects.

The researcher's view is directed to their object of study as something in constant movement; therefore, it seeks to capture the object through a historical perspective of dynamic changes between a qualitative and quantitative nature, based on concrete situations and on the contradictions of the conjunctural dynamics to which it is committed. We recall the power of the metaphor introduced to the philosophical tradition in ancient Greece by Heraclitus, noting the coherence between the bow and the lyre, in a complex and tense dynamic that, in a way, preserves some stability and effectiveness.

Therefore, as a means to comprehend this dynamic, research allows the conception of reality as a totality, overcoming the mistaken or dichotomous understanding of quality and quantity. In this way, the expression of reality manifests itself and is comprised of both quantitative and qualitative, objective and subjective, particular and universal, all intrinsically related aspects. Their separation can only be accomplished as an analysis strategy. However, considering the "everyday life", these aspects interconnect for the sake of explaining the phenomenon as a dialectical and methodologically coherent unit. 
To isolate any one of these aspects would reduce the scope of the research down to one of its properties and would not address the totality of its elements and relationships.

The premises of research converge to appropriation in its totality, referring to the way the researcher appropriates the object, transforms it and is transformed in the investigation process, through their involvement with reality in its dynamic relationships. Although it may be individual, it is socially organized upon concrete reality, respecting the scientific field with its different acting forces, structures, and agents, facing the commitment to the expected results. Therefore, the development of the object depends on the perception of these elements combined in a dynamic relationship of properties and its higher or lower intensity concerning the object of study, which characterizes the act of researching.

Based on these assumptions and agreeing that the scientific method for the understanding of reality is not grounded on sensitive reality, but on reality as a concrete thought, we defend the comprehension of the research object in its entirety, unveiling its historical and time-space conditions and its development through quantitative and qualitative aspects. In this way, the object of knowledge is conceived not as empirical, but as the result of a dynamic process, recurrent to a series of procedures that transform the initial data, still at the empirical level, into a combination of concepts, related to the theoretical level, that is sustained by the creative cognitive activity.

\section{FINANCING}

The research was developed from the support of the Conselho Nacional para o Desenvolvimento Científico e Tecnológico (CNPq) in Brazil.

\section{REFERENCES}

ALTHUSSER, L. A favor de Marx. Rio de Janeiro: Zahar, 1979.

ANDRÉ, M. E. D. A. Etnografia da prática escolar. 7. ed. Campinas: Papirus, 2002. 
ARANALDE, M. M. Reflexões sobre os sistemas categoriais de Aristóteles, Kant e Ranganathan. Ciência da Informação, Brasília, v. 38, n. 1, p. 86-108, jan./abr. 2009. DOI: https://doi.org/10.1590/S0100-19652009000100006. Disponível em: http://www.scielo.br/pdf/ci/v38n1/06.pdf. Acesso em: 12 nov. 2019.

ARISTÓTELES. Categorias. Lisboa: Instituto Piaget, 2000.

ARISTÓTELES. Órganon: Categorias; Da interpretação; Analíticos anteriores; Analíticos posteriores; Tópicos; Refutações sofísticas. Bauru: Edipro, 2005.

BOURDIEU, P.; CHAMBOREDON, J.-C.; PASSERON, J.-C. O ofício de sociólogo. Petrópolis: Vozes, 2004.

BOURDIEU, P. Le champ scientifique. Actes de la Recherche en Sciences Sociales, [S.I.], v. 2, n. 2/3, p. 88-104, jul. 1976. Disponível em: https://www.persee.fr/doc/arss_0335-5322_1976_num_2_2_3454. Acesso em: 12 nov. 2019.

DAHLBERG, I. Knowledge organization and terminology: philosophical and linguistic bases. International Classification, Frankfurt, v. 19, n. 2, p. 65-71, 1992. Disponível em: https://www.ergonverlag.de/isko_ko/downloads/ic_19_1992_2_b.pdf. Acesso em: 12 nov. 2019.

ENGELS, F. A dialética da natureza. 6. ed. Rio de Janeiro: Paz e Terra, 2000. HABERMAS, J. Faktizität und geltung: beiträge zur diskurstheorie des rechts und des demokratischen rechtsstaats. Frankfurt: Suhrkamp, 1994.

HERÁCLITO. Heráclito. São Paulo: Abril Cultural, 1973. (Coleção Os pensadores).

JENSEN, K. B.; JANKOWSKI N. W. (ed.). Metodologías cualitativas de investigación en comunicación de masas. Barcelona: Bosch, 1993.

KANT, I. Crítica da razão pura. São Paulo: Nova Cultural, 1988. (Coleção Os pensadores, v. 2).

KOSIK, K. Dialetics of the concrete: a study on problems of man and world. Boston: Reidel Publishing, 1976.

KOSIK, K. Dialética do concreto. Rio de Janeiro: Paz e Terra, 1986.

LATOUR, B. Jamais fomos modernos: ensaio de antropologia simétrica. Rio de Janeiro: Editora 34, 1994.

LEFEBVRE, H. Lógica formal/lógica dialética. Rio de Janeiro: Civilização Brasileira, 1991.

LURIA, A. R. A construção da mente. São Paulo: Ícone, 1992. 
MARX, K. The method of political economy. In: MARX, K. A Contribution to the critique of political economy. Chicago: Charles H. Kerr, 1904. p. 292-304.

MARX, K. O método da economia política. In: MARX, K. Contribuição à crítica de economia política. São Paulo: Expressão Popular, 2008. p. 257-268.

NIETZSCHE, F. Ecce homo: how to become what you are. Nova York: Oxford University Press, 2007.

PLATÃO. Sofista. Lisboa: Fundação Calouste Gulbenkian, 2011.

PRICE, D. J. S. Little science, big science. New York: Columbia University Press, 1963.

PRICE, D. J. S. Science since Babylon. New Haven: Yale University Press, 1961.

SALES, R.; GUIMARAES, J. A. C. O método analítico-sintético de Julius Kaiser: um pioneirismo para o tratamento temático da informação.

Transinformação, Campinas, v. 29, n. 2, p. 125-139, ago. 2017. DOI: https://doi.org/10.1590/2318-08892017000200001. Disponível em: http://www.scielo.br/pdf/tinf/v29n2/0103-3786-tinf-29-02-00125.pdf. Acesso em: 12 nov. 2019.

SAUSSURE, F. Curso de linguística geral. 23. ed. São Paulo: Cultrix, 2001.

SIXTH INTERNATIONAL CONGRESS FOR THE HISTORY OF SCIENCE, 1950, Amsterdam. [Proceedings at meetings]. Bulletin of the British Society for the History of Science, v. 1, n. 5, p. 113, mar. 1951. DOI: https://doi.org/10.1017/S0950563600000439.

VEYNE, P. Como se escreve a história. Foucault revoluciona a história. Brasília: Editora UNB, 1982.

WEINGAND, D. E. Grounded theory and qualitative methodology. IFLA Journal, [S.I.], v. 19, n. 1, p. 17-26, 1993. DOI: https://doi.org/10.1177\%2F034003529301900108.

\section{QUALIDADE E QUANTIDADE COMO CATEGORIAS INDISSOCIÁVEIS DE PESQUISA}

\section{RESUMO}

Objetivo: Demonstrar teoricamente as relações entre as categorias qualidade e quantidade e sua indissociabilidade na pesquisa, argumentando que as formas de produção de um campo científico dependem da vigilância dos pesquisadores sobre 0 sistema de relações objetivas e manifestam-se como prática regida por uma metaciência 
específica. Metodologia: A argumentação é construída a partir de um referencial teórico fundamentado na filosofia. Resultados: Embora haja necessidade de identificar predicados como qualidade e quantidade para distinguir e analisar o objeto científico, esses são aspectos componentes da totalidade do objeto percebido, sendo impossível considerá-los separadamente. Conclusão: É necessário vigilância sobre o modo de construção e comunicação da pesquisa científica, incluindo suas explicações e enunciados, a partir da consideração sobre o aspecto relacional dos predicados na sua determinação dupla, investigação e exposição, relativa ao processo de apropriação e explicitação crítico-racional.

Descritores: Método científico. Predicados da Pesquisa. Complementaridade. Metaciência.

\title{
CALIDAD Y CANTIDAD COMO CATEGORÍAS INSEPARABLES DE INVESTIGACIÓN
}

\begin{abstract}
RESUMEN
Objetivo: Demostrar teóricamente las relaciones entre las categorías de calidad y cantidad y su inseparabilidad en la investigación. Sostiene que las formas de producción en un campo científico dependen de la vigilancia de los investigadores sobre el sistema de relaciones objetivas y se manifiestan como una práctica realizada por una metaciencia específica. Metodología: Construye la argumentación a partir de un marco teórico basado en la filosofía. Resultados: Reconoce que, si bien es necesario identificar caracteres como la calidad y la cantidad para distinguir y analizar el objeto científico, estos son aspectos componentes de la totalidad del objeto percibido y es imposible considerar estos personajes por separado. Conclusión: Concluye abogando por la vigilancia sobre la forma en que se construye y comunica el conocimiento en la investigación y sus explicaciones y enunciados desde la consideración del aspecto relacional de los personajes en su doble determinación, investigación y exposición relacionada con el proceso de apropiación y explicación crítico-racional.
\end{abstract}

Descriptores: Método científico. Predicados de la Investigación. Complementariedad. Metaciencia.

Recebido em: 14.11.2021

Aceito em: 17.11.2021 